Copyright (C) 2021 by Cherkas Global University

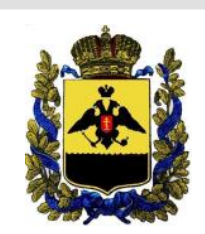

Published in the USA

Bylye Gody

Has been issued since 2006.

E-ISSN: $2310-0028$

2021. 16(4): 1935-1946

DOI: $10.13187 /$ bg.2021.4.1935

Journal homepage:

https://bg.cherkasgu.press

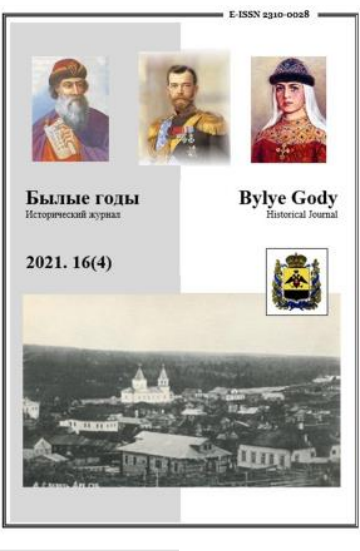

\title{
The "Truth" and the "Falsehood" of the Suvorov Soldier: The Problem of Authorship of Ilya Popadichev's Memoirs
}

\author{
Tatiana A. Volodina a , *, Konstantin A. Podrezov a \\ a Tula State Lev Tolstoy Pedagogical University, Russian Federation
}

\begin{abstract}
For the first time in history researches, the article analyzes the specifics of the "Memoirs of a Suvorov Soldier" as a historical source. These memoirs have been widely used in non-fiction history literature and researches since their appearance (1895). On the basis of archival documents for the first time introduced into research the authors study the circumstances of its appearance, writing and publication. The authors analyze the motives and the role of each person who did his part to creating the text: retired soldier Ilya Popadichev, General I. N. Nazansky and military historian D. F. Maslovsky. As a result, the source appears as a comprehensive complicated text, in which various layers with different origins are highlighted. Using the facts of the military biography of real Ilya Popadichev, the authors explain the varying degrees of content accuracy and information completeness inherent in the book. Analyzing the letters of General Nazansky to the historian Maslovsky, the authors reveal the influence of various factors in the general's work on the memoirs: ideological and conceptual reasons as well as pragmatic and commercial considerations. The article reveals the role and significance of the Military-Scientific Committee of the General Staff in the formation mass-market book products intended for circulation in the troops. As a result of the conducted research, the authors come to the conclusion that Popadichev's memoirs are not only a reflection of the military-historical realities of Suvorov time. To a large extent, they are evidence of the intentional efforts of the military department to indoctrinate the lower ranks, as well as the fact of the conceptual controversy in the field of military history researches of the late XIX century. The authors prove that was the reason for the serious role of D. F. Maslovsky in promoting Popadichev's memoirs. However, in this case, the positivist principles of science came into collision with the myth. The article reveals the depth of the moral dilemma faced by the military historian Maslovsky. Science demanded from him a critical analysis of the source, and his commitment to the "Russian school" values required the high merits of the memoirs to be claimed and recognized.
\end{abstract}

Keywords: "Memoirs of a Suvorov soldier", Popadichev, D. F. Maslovsky, military history researches.

\section{1. Введение}

Среди мемуарных источников XVIII - первой половины XIX вв. военная тема занимает прочные позиции. Однако только четыре сочинения принадлежат перу тех, кто тянул солдатскую лямку (Записки Памфила Назарова, 1878; Воспоминания Ивана Меньшого, 1874; Воспоминания, 1895; Старков, 1847). Впрочем, далеко не все из этих воспоминаний выглядят убедительно в отношении «солдатскости» и аутентичности. В данной статье мы попытаемся проанализировать обстоятельства и причины появления «Воспоминаний суворовского солдата», которые очень часто именуются просто - «мемуары Попадичева».

Впервые это сочинение было напечатано в 1895 г. Имени автора на титуле не значилось, зато присутствовал солидный подзаголовок: «Издано при пособии Военно-ученого комитета Главного штаба. Под редакцией покойного Генерального штаба генерал-майора Д.Ф. Масловского».

\footnotetext{
${ }^{*}$ Corresponding author
}

E-mail addresses: volodina.tatiana2016@yandex.ru (T.A. Volodina), kpodrezov@yandex.ru (K.A. Podrezov) 
Повествование велось от лица неизвестного офицера, встретившего в 1854 г. в Пятигорске старикаветерана, которому перевалило за сто лет. Этот седой отставной солдат, на груди которого красовались различные награды (медали за штурм Очакова, Измаила и Праги, георгиевский крест и медаль за 1812 г.), и рассказывает анонимному автору о своем боевом пути. Рассказчик выступает в книге под именем Ильи Осиповича Попадичева. Воспоминания его разделены на две части: «Драгун», которая посвящена службе в Смоленском драгунском полку, и «Гренадер», где описана его служба в Бутырском пехотном полку. В первой части Попадичев описывает события русско-турецкой войны 1787-1791 гг., сражения против армии Костюшко и штурм Праги, во второй - речь идет об итальянском и швейцарском походе Суворова.

Позднее в издательстве В.А. Березовского вышли два переиздания этой книги (1899 и 1907 гг.). Однако этим дело не ограничилось: в том же издательстве вышло несколько брошюр, которые были представлены публике как отдельные главы воспоминаний того же Ильи Попадичева (Воспоминания. Очаков и Измаил, 1900; Воспоминания. 1812-й год, 1901; Воспоминания. Аустерлиц, 1903; Воспоминания. Отставка, 1907). В этих брошюрах (на титуле или на последней странице) появились загадочные инициалы - Н.И.Н.

В связи со всем этим возникает целый комплекс вопросов. Откуда, собственно, взялся текст этих воспоминаний? Существовал ли на самом деле отставной суворовский солдат Илья Осипович Попадичев? Был ли он автором данных текстов? Когда они были написаны? Если в воспоминаниях описываются времена Суворова, то где находился столь драгоценный источник вплоть до конца ХІХ в.? Каким боком к этому изданию причастен Д.Ф. Масловский? И что за таинственная фигура обозначена инициалами Н.И.Н.? В данной статье мы попытаемся отыскать ответы на поставленные вопросы.

\section{2. Материалы и методы}

Помимо собственно воспоминаний Ильи Попадичева, основную роль в исследовании играют материалы, обнаруженные в фондах Отдела рукописей Российской государственной библиотеки (г. Москва, Российская Федерация) и Российского государственного военно-исторического архива (г. Москва, Российская Федерация). Нами были использованы документы из личного фонда Д.Ф. Масловского (ОР РГБ. Ф. 563. Карт. 2. Д. 16; Д. 52; Д. 53), которые позволили раскрыть его роль в судьбе этих мемуаров. Были также использованы различные документы из фондов РГВИА, которые можно разделить на три тематические группы. Первая - касается документов, связанных с реальным Ильей Попадичевым: формулярные списки Смоленского драгунского полка за 1793 и 1799 гг. (РГВИА. Ф. 489. Оп. 1. Д. 2583; Д. 2587) и месячные ведомости Бутырского пехотного полка за 1812 г. (РГВИА. Ф. 489. Оп. 1. Т. 1. Ч. 1. Д. 136). Вторая - раскрывает реалии деятельности Военно-ученого комитета по рассмотрению сочинений, предназначенных для армии (РГВИА. Ф. 401. Оп. 2. Д. 26 за1867 г.; Ф. 401. Оп. 5/929. Д. 26 за 1894 г.). Третья же - связана с документами, которые касаются карьеры и биографии представителей семейства Назанских (РГВИА. Ф. 409. Оп. 1. Д. 132782; Ф. 400. Оп. 17. Д. 10466).

В плане методологии в исследовании использовались общенаучные методы логического анализа, основанные на принципах историзма. При работе с архивными материалами и опубликованными источниками применялись принципы источниковедческого анализа и текстологии для выявления истории создания «Воспоминаний суворовского солдата», а также для реконструкции роли различных людей и институтов в данном процессе. Это позволило проанализировать мемуары Попадичева в контексте взаимодействия научных, идеологических и социокультурных факторов в формировании концептуального осмысления военной истории в конце XIX в.

\section{3. Обсуждение}

Судьба «Воспоминаний суворовского солдата» примечательна и парадоксальна. Когда в начале $\mathrm{XX}$ в. развернулось настоящее соревнование по написанию полковых историй, то авторы истории Смоленского полка, не мудрствуя лукаво, разделы, посвященные 1780-1790-м годам, писали практически «по Попадичеву» (Годунов, Королев, 1908: 44-84). Указания на «Воспоминания суворовского солдата» мы обязательно найдем во всех библиографических указателях литературы о Суворове. За последние десятилетия они даже неоднократно переиздавались (Богуславский, 1953: 585, 588, 591; Лопатин, 2012: 128-129, 445; Охлябинин, 2004: 274-342; Слово Суворова, 200о: 58-107). Особенно востребованы мемуары Попадичева среди исторических реконструкторов, которые считают их «непревзойденным источником для изучения истории военных походов, которыми по непонятным причинам пренебрегают академические историки» (Преснухин, 2021). Действительно, наблюдается некая закономерность: чем более популярный характер носит та или иная работа, тем более восторга вызывают мемуары Попадичева, в академических же исследованиях к ним относятся с известной настороженностью. Признанный корифей суворовской темы А.Ф. Петрушевский во втором издании своей книги, характеризуя вновь появившиеся публикации, упомянул и эти мемуары, но мягко выразил сомнение насчет достоверности их содержания: «Рассказчик помнит очень немногое, ибо слова его записаны через столетие после излагаемых событий» (Петрушевский, 19о0: 806). Эта туманная фраза Петрушевского порождала вопросы. А кто и когда, собственно, записал эти 
рассказы и сколько лет рассказчику, если речь идет о событиях столетней давности, в которых он якобы принимал деятельное участие?

\section{4. Результаты}

Имя Масловского, вынесенное на обложку «Воспоминаний суворовского ветерана», безусловно, должно было вызывать у современников доверие к книге, ведь Дмитрий Федорович был известным военным историком, который пользовался заслуженным уважением в ученом мире благодаря прекрасным работам по военной истории XVIII века и глубоким архивным исследованиям. Окончив академию в 1873 г., Масловский был причислен к офицерам Генерального штаба. В боевых действиях он не участвовал, служил в основном при штабе Московского округа. Карьерный рост он обеспечил себе благодаря военно-историческим исследованиям. В 1889 г. этот московский полковник, получив объявленное в приказе «монаршее благоволение за труды по военной истории», был назначен адъюнкт-профессором в Николаевскую академию Генерального штаба. В 1890-е гг. Масловский уже получил чин генерал-майора, стал профессором и занял только что учрежденную в академии кафедру истории русского военного искусства (ОР РГБ. Ф. 563. Карт. 2. Д. 53. Л. 12-19).

В случае с «Воспоминаниями суворовского солдата» его имя добавляло изданию веса и даже создавало иллюзию, что сам Масловский, вероятно, и был тем самым «неизвестным офицером», который в 1854 г. записывал речи седого ветерана. Однако родился он в 1848 г. и, разумеется, никак не мог вести такие беседы в шестилетнем возрасте. Настораживает и еще один факт: Масловский умер в начале ноября 1894 г., а книга была опубликована в 1895 г. По понятным причинам покойный генерал-майор не мог подтвердить или опровергнуть факт своего «редакторства», а также объяснить, в чем именно оно состояло.

В фонде Д.Ф. Масловского сохранилась любопытная переписка, которая позволяет пролить свет на обстоятельства появления этой книги (ОР РГБ. Ф. 563. Карт. 2. Д. 16). Письма принадлежат Ивану Николаевичу Назанскому, генерал-майору и командиру 2-й бригады 19-й пехотной дивизии, располагавшейся в Киевском военном округе. Первое письмо датировано 11 октября 1893 г., а последнее - 21 июня 1894 г. В деле, естественно, нет писем самого Масловского, мы слышим только одну сторону этого эпистолярного диалога. Тем не менее эта переписка позволяет нам в определенной степени восстановить историю взаимоотношений петербургского профессора и киевского генерала.

В фондах РГВИА сохранилось дело, относящееся к 1897-1898 гг., - «О производстве с увольнением от службы генерал-майора Назанского» (РГВИА. Ф. 400. Оп. 17. Д. 10466). Оно дает нам возможность ознакомиться с биографией Назанского и до некоторой степени обрисовать его психологический облик. Практика присвоения следующего чина с одновременным выходом в отставку была достаточно распространенной в армии, и Назанскому тоже предназначался при выходе в отставку чин генерал-лейтенанта, однако он принялся хлопотать, и достаточно настойчиво, об усиленной пенсии. В ходе рассмотрения его прошения всплыли некоторые нюансы, о которых речь пойдет ниже.

Родился Иван Назанский в 1822 г., происходил из дворян Новгородской губернии. Образование он получил в Новгородском графа Аракчеева кадетском корпусе, откуда был выпущен прямиком в армию. В 1846-1848 гг. учился в академии Генерального штаба и окончил ее по 1-му разряду. Назанский участвовал в боевых действиях: в 1849 г. - в Австрии, в 1851-1855 гг. - на Кавказе, а в 1863 г. - в сражениях против польских повстанцев (РГВИА. Ф. 400. Оп. 17. Д. 10466. Л. 62-72). Вероятно, был контужен, ибо в 1861 г. ему было разрешено «для облегчения болезненных припадков головы носить вместо кивера фуражку» (РГВИА. Ф. 400. Оп. 17. Д. 10466. Л. 66). Однако в этом успешном продвижении от прапорщика до генерала было одно темное пятно: в ноябре 1875 г. полковник Назанский попал под суд и был отставлен от службы - «за излишнее требование от казны денег и материалов на содержание нижних чинов и батальонных зданий, незаписание на приход денег, вырученных от продажи экономических материалов, и другие преступления» (РГВИА. Ф. 400. Оп. 17. Д. 10466. Л. 46 об.). Короче говоря, Назанский проворовался. Только три года спустя ему удалось вернуться на военную службу с высочайшим повелением: «Понесенное наказание не считать препятствием к наградам по службе, не относя сего прощения к праву на получение знака о беспорочной службе» (РГВИА. Ф. 400. Оп. 17. Д. 10466. Л. 46об.). Кстати, в 1898 г. генерал сумел-таки выхлопотать себе пенсию по повышенному разряду.

Какое интересное сочетание черт мы видим: достаточно высокий интеллектуальный уровень (за плечами академия), реальный боевой опыт, умение успешно выстраивать связи и коммуникации (с наименьшими потерями выскользнул из-под суда) и, наконец, не слишком щепетильное отношение к казенным деньгам и отчетной документации. Судя же по письмам его к Масловскому, Назанский был еще и тонким психологом. Он явно имел перед собой некую цель, к достижению которой решительно и устремился.

Первые письма исполнены изощренной лести. Назанский пишет о том, с каким глубоким интересом он следит за статьями Масловского в «Военном сборнике», какую великую задачу выполняет тот, обращаясь к изучению традиций русского воинского искусства, как была бы полезна 
профессору помощь учащихся в академии офицеров в составлении карт и как низки его, Масловского, оппоненты, с которыми профессору даже не стоит вступать в полемику. Что могло быть слаще для военного историка, нежели прочесть: «В здешней библиотеке статью Петрова пришлось разрезывать, потому что она не прочитана, а ваши статьи в № 8 и 9 «Военного сборника» все разрезаны, значит, офицерство их прочло... Всему виной проклятая компиляция - ваш оппонент нахватался этого духа и размазывает, бумага все терпит» (ОР РГБ. Ф. 563. Карт. 2. Д. 16. Л. 9 об.). Здесь имеется в виду полемика между Масловским и военным историком, генерал-майором А.Н. Петровым. Оба занимались проблемами военной истории XVIII в., и в 1893 г. на страницах «Военного сборника» между ними развернулась своеобразная научная дуэль (Масловский, 1892a; Масловский, 1892b; Масловский, 1894; Петров, 1892; Петров, 1893a; Петров, 1893b). Заметим, кстати, что Петров в этой полемике отнюдь не выглядел «слабым компилятором».

Уже в ноябрьском письме Назанского ювелирно замаскирована наживка. Обсуждая тактику Суворова в 1794 г. (стремительность, погром врага, чтобы посеять панику по всей Польше), Назанский приводит текст солдатской песни суворовских времен о Мацеёвицах: «Слух Костюшки достигает, Сераковский в прах разбит...» (ОР РГБ. Ф. 563. Карт. 2. Д. 16. Л. 7-7 об.).

Генерал Назанский раскрывает и обстоятельства, при которых он получил эту песню. Когда-то, в 1853 г. (впоследствии в тексте книги будет говориться о 1854 г.), он встретил в Пятигорске 105-летнего старика, чьи рассказы о боевом прошлом молодой офицер скрупулезно записывал, вот со слов этого-то старика и была записана песня. Дальнейшее предугадать нетрудно, не мог военный историк, который занимался XVIII веком, не заинтересоваться такой рукописью, и Назанский отправляет ее в Петербург. Следует отметить еще одно немаловажное обстоятельство: уже в ноябрьском письме Назанский поздравляет своего визави с избранием в члены Военно-ученого комитета (ОР РГБ. Ф. 563. Карт. 2. Д. 16. Л. 5).

Судя по письмам, объем этой рукописи был гораздо больше, нежели текст издания 1895 г. Все, что будет напечатано после 1895 г. отдельными брошюрами (Очаков, Измаил, Аустерлиц, война 1812 г., отставка), - все это в рукописи содержалось изначально. Помимо первых двух частей («Драгун» и «Гренадер»), в рукописи была еще и третья часть под названием «Бабушкин солдат», в которой шла речь о жизни в отставке: как Попадичев встречался с сиятельным князем М.С. Воронцовым и долго беседовал с ним, рассказывая о проезде Екатерины Великой, которую он видел собственным глазами во время ее путешествия на юг; как Воронцов выхлопотал ему пенсию и как сам император Николай Павлович при встрече с Попадичевым тепло назвал его «бабушкиным солдатом».

Если суммировать все тексты, которые печатались как «воспоминания Попадичева», то охват событий, свидетелем которых он был, поистине поражает. Он своими глазами видел, как во время путешествия Екатерины в Крым по бокам ее экипажа идут Потемкин в блестящем мундире и Суворов в скромном кителе. К его костру подсаживается неузнанный Суворов, ест, нахваливая, солдатскую кашу, а потом спит на земле, завернувшись в плащ. Он участвует в осаде Очакова и в штурме Измаила. Он рассказывает о неприязни Потемкина к Суворову. Он сражается при Мацеёвицах и принимает участие в штурме Праги, видит, как попадает в плен раненый Костюшко. Он проходит с Суворовым Италию и Швейцарию. На него накануне Аустерлица глядит в лорнетку император Александр. Он воюет с французами в 1812 г. и попадает к ним в плен. И наконец, как достойное завершение - он беседует с могущественным хозяином Новороссии князем Воронцовым. Рождается законное сомнение: не слишком ли много для одного солдата?

И в этой связи мы возвращаемся к вопросу: зачем Назанскому понадобился Масловский? Он ведь и сам мог издать «Воспоминания суворовского солдата». Однако в таком случае это было бы воспринято как еще одно беллетризованное описание суворовских побед, вложенное в уста человека из простонародья. Это была бы далеко не новость, по мере складывания легендарного образа Суворова такого рода популярные сочинения уже не раз были напечатаны (Новаковский, 1867; Полевой, 1852; Потапов, 1845; Петрушевский, 1885). Лучше было не «светить» свое имя на обложке издания, формулировка «под редакцией Масловского» звучала гораздо более весомо, придавая изданию выверенный и академический характер, делая его «историческим источником».

Масловский в глазах Назанского мог являться эффективным драйвером в продвижении мемуаров Попадичева в силу еще двух причин - коммерческой и идейной. Первая, коммерческая, заключалась в том, что Масловский был членом Военно-ученого комитета Главного штаба. В пореформенное время в круг обязанностей этого органа, помимо всего прочего, входило «развитие военного образования в армии и грамотности в войсках», а также «рассмотрение сочинений, предназначаемых для войск» (ПСЗРИ. № 46611 от 1 января 1869 г.; № 58773 от 14 августа 1878 г.). Те издания, которые получали одобрение комитета, включались в циркуляры Военного министерства как книги, одобренные к обращению в войсках. На практике, с тех пор как с 1859 г. в военном бюджете стали выделяться деньги на развитие грамотности и солдатского чтения (Библиотеки солдатские, 1911: 537), попадание издания в библиографическую обойму военного ведомства сулило ему коммерческий успех за счет массовости такого казенного спроса. Опытные издатели, представляя на рассмотрение Военно-ученого комитета свои книги, даже спешили прислать солидное количество (4-6 тыс.) отпечатанных рекламных листков, которые Главный штаб рассылал в войска вместе со 
своими циркулярами (РГВИА. Ф. 401. Оп. 2. Д. 26 за 1867 г. Л. 101). Косвенно это дает нам возможность представить потенциальную емкость рынка такой продукции.

В письмах Назанского содержится много черточек, которые позволяют думать, что о коммерческой стороне предприятия он думал серьезно. И очевидно, что вырученные деньги они договорились определенным образом разделить с Масловским. Генерал пеняет Масловскому, что с первоначально планируемой цены (50 коп.) тот предлагает снизить цену книжки вдвое, и добавляет: «Я искренне желаю, чтобы ваш высокоценный труд был хорошо оплачен» (ОР РГБ. Ф. 563. Карт. 2. Д. 16. Л. 20об.). В это время сын его - Николай Иванович Назанский (вот и всплыл тот, кто скрывался за инициалами Н.И.Н.) - как раз переводился из армии в лейб-гвардию. Согласно послужному списку, поручик Назанский, 1868 года рождения, окончивший Киевский кадетский корпус и Павловское военное училище, летом 1893 г. держал экзамены в академию, но без успеха (РГВИА. Ф. 409. ОП. 1. Д. 132782. Л. 110-115).

Следовало искать альтернативных путей карьерного роста, и в декабре 1893 г. Назанскиймладший переводится в 1-й Лейб-гвардии стрелковый батальон, располагавшийся в Царском Селе. А в середине октября Назанский-старший написал первое письмо Масловскому. Вряд ли это было простым совпадением, связи и протекция в Петербурге сыну бы не помешали. Киевский генерал не скрывал и своего коммерческого интереса: «Желание мое состоит в том, чтобы сын мой при переводе в гвардию извлек из этого [публикации рукописи] средства на обмундирование и на необходимую обстановку» (ОР РГБ. Ф. 563. Карт. 2. Д. 16. Л. 17 об.). О перспективах издания в случае его одобрения Военно-ученым комитетом он тоже был прекрасно осведомлен и (во всяком случае, в Киевском военном округе) распространение книги гарантировал. Он сообщал своему корреспонденту: «Сыну моему выслал выписку о частях, в которые Учебный комитет мог бы выслать указанное по числу рот, эскадронов и батарей число экземпляров с представлением за них денег. Таким образом, издание быстро бы разошлось, с избытком вознаградив за труд всех» (ОР РГБ. Ф. 563. Карт. 2. Д. 16. Л. 220б.). Кстати, заметим, что ожидания Назанского в этом плане полностью оправдались. «Воспоминания суворовского солдата» попали и в циркуляры Главного штаба, и в серию «Солдатская библиотека», издаваемую В.А. Березовским, и в каталоги книг, рекомендованных кадетам (Каталог, 1907: 77)².

Вторая причина, которую можно назвать «идейно-концептуальной», была гораздо серьезнее и глубже. Дело в том, что в военно-исторической науке того времени (которая была сосредоточена в первую очередь в стенах академии) достаточно четко выделялись два крыла: «русская» и «академическая» школа. Вопрос о научных столкновениях и подводных течениях в Николаевской академии мало изучен в исторической науке, если он и рассматривался, то главным образом в контексте вопроса подготовки офицерских кадров или же в связи с историей Генерального штаба (Зайончковский, 1952: 230-233; Mayzel, 1975; Wildman, 1980). Однако еще Л.Г. Бескровный отмечал феномен, который проявился в стенах академии в пореформенное время - развернувшуюся борьбу между академической и русской школой (Бескровный, 1962: 182-188). Представители русской школы делали акцент на самобытности и превосходстве русского военного искусства по отношению к европейскому. Академисты же подчеркивали единые закономерности в развитии военного искусства как такового и связывали эти закономерности с социальными, историческими и техническими факторами. Своеобразной иллюстрацией (конечно, упрощенной), символизирующей различие в подходах этих двух школ, может служить эпизод из жизни молодого М.Д. Скобелева во время учебы его в академии. На практических испытаниях ему было дано задание отыскать и обосновать место переправы через Неман, для чего требовалось провести рекогносцировку всего течения реки. Скобелев не двинулся с места, а когда явилась экзаменационная комиссия во главе с генералом Г.А. Леером, вместо всяких выкладок и расчетов он вскочил на коня и переправился через реку туда и обратно (Немирович-Данченко, 1903: 9).

Масловский как раз и был одним из лидеров русской школы. Это чувствовали и понимали современники, это сознавал и сам Масловский. Недаром он бережно хранил в своем архиве список статьи из «Московского листка» и незадолго до смерти сделал на ней пометку, как будто оставляя завещание: «Эта заметка - для моего Сергея [сын Масловского]. Принадлежит перу Е.В. Барсова. Он чувствовал искренность и даже святость моих убеждений» (ОР РГБ. Ф. 563. Карт. 2. Д. 52. Л. 20б.). А статья действительно была прелюбопытная, исполненная гнева и сарказма в адрес академии и Петербурга. В ней московский историк как невиданный случай отмечал первое избрание москвича в адъюнкт-профессоры военной академии, указывая, что работы Масловского кардинально отличаются от «работ петербургской военной фабрикации». История русского военного искусства, по его мнению, находится там в небрежении, пишется «исключительно из немецких книжек и сквозь немецкую призму», а курс военной русской истории и вовсе много лет не преподается. В глазах Барсова появление Масловского в академии послужит «к утешению всех русских сердец» (Барсов, 1889).

Именно поэтому в своих научных исследованиях Масловский обращался к сюжетам XVIII столетия, именно поэтому главными героями в его работах были Петр I, Румянцев, Потемкин и,

1 Различные части «Воспоминаний суворовского солдата» входили в комплекты серии «Солдатская библиотека» В.А. Березовского (комплект 9, № 175; комплект 13, № 250, 252, 253) 
конечно, Суворов. Масловскому «был нужен» Попадичев как подтверждение эффективности формирования особенных нравственных качеств русского солдата и особенных взаимоотношений между солдатами и их полководцами в российской армии. Вот почему Назанский и выбрал его для продвижения «Воспоминаний суворовского солдата». Впрочем, необходимо отметить, что киевский генерал и сам придерживался сходных взглядов. Множество замечаний рассыпаны в его писымах, и явно не только для того, чтобы подольститься к Масловскому: «Наука побеждать» явилась раньше мыслей Наполеона! Но какая-то злая судьба-мачеха всегда толкала нас в неметчину... Главнокомандующий русской армией должен быть природный русский человек! Великая истина!.. Вот те тайны военного искусства, которые не подлежат книжному изучению, а совмещаются в личности самого Вождя [Суворова]» (ОР РГБ. Ф. 563. Карт. 2. Д. 16. Л. 16-16 об., 27). У Назанского то и дело проскальзывают нотки скепсиса в отношении постмилютинской армии: «Неужто нынешние военные писатели будут так наивны, что, возмечтав о превосходстве нынешнего скоропеченого солдата над прежним, ...откажут нашим отцам и дедам в их значении» (ОР РГБ. Ф. 563. Карт. 2. Д. 16. Л. 22).

В общем, они нашли друг друга. В 1893 г. поручик Назанский (т.е. сын) обратился с ходатайством в Военно-ученый комитет, в котором сообщал, что владеет рукописью воспоминаний суворовского солдата, «достоинство которой засвидетельствовано членом Военно-Ученого комитета генерал-майором Масловским». Поручик просил разрешения напечатать ее в «Военном сборнике» с примечаниями Масловского, а ему, Назанскому, «оказать спомоществование», выдав 4 тыс. экземпляров отдельною книжкою в качестве чтения для солдат (РГВИА. Ф. 401. ОП. 5/929. Д. 26 за 1894 г. Л. 199). Задумано было неплохо: напечатать мемуары Попадичева в самом значительном органе военной периодики, под патронажем Масловского, да еще и получить за казенный счет тираж, который гарантированно разойдется по войсковым частям.

По установленной процедуре два члена комитета должны были дать свое заключение по поводу представляемого сочинения. В данном случае это были Н.Ф. Дубровин и Н.А. Орлов ${ }^{1}$ В деле сохранилось письмо Масловского к Орлову (РГВИА. Ф. 401. Оп. 5/929. Д. 26 за 1894 г. Л. 200-203). В письме он дает очень высокую оценку научным достоинствам воспоминаний, которые, по его мнению, «превосходят известные «Рассказы старого воина»². Масловский настаивает, что обычного гонорара за публикацию в «Военном сборнике» в этом случае будет недостаточно, и предлагает выделить Назанскому дополнительно 1600 руб. Он подтверждает, что готов снабдить публикацию примечаниями и просит комитет серьезно подойти к рассмотрению этой рукописи. Масловский в это время уже тяжело болен. Извиняясь перед Орловым за то, что не приехал к нему лично, он объясняет: «Каждая поездка, даже в Главный штаб, вызывает усиление боли от тряски и даже кровь» (РГВИА. Ф. 401. ОП. 5/929. Д. 26 за 1894 г. Л. 201).

Казалось, что счастливая судьба «воспоминаний Попадичева» уже решена. И вдруг что-то пошло не так. Отзвук этого мы находим в письмах Назанского, который пишет Масловскому: «Очень сожалею, что Суворовский солдат наделал вам массу беспокойств» (ОР РГБ. Ф. 563. Карт. 2. Д. 16. Л. 25). Из писем ясно, что идея публикации в «Военном сборнике» оказалась неосуществима, что при обсуждении рукописи рецензенты стали указывать на явные фактические ошибки и несоответствия в тексте. Масловский и сам был высокопрофессиональным историком, дотошным и скрупулезным, прекрасно знакомым с приемами критики источников. Он обладал большим опытом архивных изысканий и публикации источников. Принявшись за работу над примечаниями, он не мог не заметить странностей текста. Сначала он приходит к выводу, что нужно вообще исключить из публикации Очаков, Измаил, Аустерлиц, 1812-й год и жизнь в отставке (очевидно, эти фрагменты вызывали наибольшие сомнения по части аутентичности). А потом и вовсе пишет Назанскому письмо с обширным перечнем несообразностей, которые ставили вопрос о достоверности воспоминаний в целом. Мы можем судить об этом перечне лишь по ответам Назанского, который всеми правдами и неправдами пытался выгородить своего героя.

Среди вопросов Масловского были, например, следующие. Как мог Попадичев участвовать в штурме Измаила, если Смоленский драгунский полк был выведен с театра военных действий 14 марта 1789 г., а Измаил был взят только в декабре 1790 г.? Да и с итальянским походом все выходило как-то смутно: непонятно, в составе какой части он мог попасть в Италию. Почему Попадичев называет Багратиона и Милорадовича, но не упоминает своих непосредственных командиров? Как он мог понимать смысл стратегических маневров, роль корпуса Корсакова и т.п.?

Вот тут Назанскому пришлось несладко, он пускает в ход различные аргументы. Во-первых, старик за старостью мог многое забыть или перепутать, мог и прихвастнуть для красного словца. И рядом - противоположное: «Думать, как он мог знать то и это - жалкое заблуждение... У Суворова не пустые слова были, что каждый рядовой должен понимать свой маневр, а начальники должны чертежам давать наглядное объяснение... К тому же Попадичев был грамотным унтер-офицером. Был

\footnotetext{
1 Генерал-майор Николай Федорович Дубровин и полковник Николай Александрович Орлов военные историки, оба в это время состояли членами Военно-ученого комитета и были авторами работ по военной истории XVIII в.

2 Здесь имеется в виду издание М.П. Погодина: Рассказы Старого воина о Суворове. Москва, 1847. 
часто назначаем ординарцем и мог слышать разговоры начальствующих лиц» (ОР РГБ. Ф. 563. Карт. 2. Д. 16. Л. 21). В Италию, утверждает Назанский, он попал не со своим полком, а в составе сводного гренадерского батальона Санаева. «Что же касается до того, что батальон Санаева существовал, то в этом я вам порукой, и отвечаю, чем хотите - военную историю я знаю хорошо... Известно, что тех сводных гренадерских батальонов было всего 4, которые назывались по именам своих командиров... Названия их имеются в оправдательных документах, приложенных к Истории Суворова 1799 г., составленной Милютиным... Где упомянуто его имя [Санаева], там ищите и старика, и приписывайте в текст его участие, округляйте и исправляйте рукопись, иначе обойтись нельзя» (ОР РГБ. Ф. 563. Карт. 2. Д. 16. Л. 25 об., 26 об.). Здесь имеется в виду фундаментальная работа Д.А. Милютина «История войны России с Францией в 1799 г.» (2-е изд. 1857 г.), по которой можно было документально проследить боевой путь батальона Санаева (Милютин, 1857: 169, 195, 202, 203, 220, 331, 489, 535, 547, 555, 643).

После таких откровенных советов у Масловского не могло не зародиться подозрение: а уж не делал ли это все сам Назанский, «округляя и исправляя» текст и справляясь при случае с военноисторическими монографиями? А Назанский идет далее и почти сбрасывает маску: «Взгляните на дело несколько хладнокровнее... Вы задались целью прославить русское военное искусство в век Екатерины, Румянцева и Суворова. Я даю вам живой образчик этого. Вы делаете ему примечания, выводите его на пьедестал [подчеркнуто в оригинале]. И вдруг из-за Измаила, который старик мог спутать с другим турецким городом, Вы лишаете его даже права быть предметом прочтения образованными людьми в «Военном сборнике». Кто потеряет? Я или Вы?» (ОР РГБ. Ф. 563. Карт. 2. Д. 16. Л. 37-37 об.). А ведь он тем самым ставил Масловского перед нелегким моральным выбором. Попадичев действительно прекрасно «ложился» в концепцию историка об особом нравственном облике русского солдата, об особенных связях, которые формировались между солдатами и полководцами, об инструментах формирования этих связей. И в то же время от мемуаров Попадичева за версту тянуло «сочинительством».

Перед лицом такой дилеммы ученый все-таки одержал верх над представителем «русской школы». В архивном деле сохранилась телеграмма, которую 18 мая 1894 г. в адрес главы Военноученого комитета генерала Ф.А. Фельдмана отправил смертельно больной Масловский: «Подстрочная оценка рассказа Суворовского солдата обнаруживает крупную путаницу. Испрашиваю обождать ходатайством пособия Назанскому» (РГВИА. Ф. 401. Оп. 5/929. Д. 26 за 1894 г. Л. 265). Становится ясным, почему «Воспоминания суворовского солдата» с указанием редакторства Масловского были опубликованы только после его смерти. А уже позднее предприимчивый и рачительный поручик Николай Иванович Назанский (Н.И.Н.) представил изначально забракованные Масловским фрагменты (Очаков и Измаил, Аустерлиц, 1812 год, жизнь в отставке) в издательство В.А. Березовского (в самом деле, не пропадать же добру). Издания Березовского никак не претендовали на статус «научности и достоверности». В комплекты «Солдатской библиотеки» целенаправленно отбиралось то, что рассматривалось как поучительное и занимательное чтение для солдат и народа. Однако на этот шлейф популярных брошюр все равно ложился отсвет «Воспоминаний суворовского солдата», которые всегда на титуле имели подзаголовок «под редакцией покойного Генерального Штаба генерал-майора Д.Ф. Масловского».

Остается главный вопрос: а, собственно говоря, был ли Попадичев? Встречал ли молодой офицер в действительности седоусого ветерана в Пятигорске, который рассказывал ему о сражениях прежних времен? Это мы можем проверить. В фондах РГВИА сохранились формулярные списки Смоленского драгунского полка, и в списках за 1793 и 1799 годы значится Илья Осипов сын Попадичев (РГВИА. Ф. 489. Оп. 1. Д. 2583. Л. 79 об.-80; Д. 2587. Л. 89-91). Наиболее подробная информация о его службе содержится в списке за 1799 г., правда, название полка в это время звучит следующим образом - «драгунский фон Бринкена полк» (при Павле географические названия полков были отменены, они стали называться по имени командиров). Из документов видно, что в 1799 г. Попадичев все еще находился в Смоленском драгунском полку (а не в Бутырском пехотном и не в сводном гренадерском батальоне). В 1799 г. ему было 26 лет, т.е. родился он в 1773 г. Происходил он из дворян Воронежской губернии, о чем в полку имелось выданное от предводителя дворянства свидетельство. Поступил на службу в июле 1786 г. в Смоленский драгунский полк рядовым, а унтерофицерское звание получил в 1798 г. Попадичев умел «читать и писать по-российски», однако не был аттестован (а это давало возможность для повышения в следующее звание) «за еще недовольную успешность поведения».

Здесь же перечислялось, в каких походах и делах против неприятеля он участвовал: во время турецкой кампании в охранении над бугским и днепровским лиманом (август-ноябрь 1787 г.) и в обсервационном корпусе в укреплении на реке Каланчак (апрель-декабрь 1788 г.). Заметим, расстояние между Каланчаком и Очаковым около двухсот верст. А вот в 1792-1794 гг. Попадичев действительно «находился в неоднократных сражениях с противной фракцией» (на бюрократическом языке так именовались польские войска, боровшиеся против второго раздела Польши). Он участвовал в битве под Щекоцинами, в сражении при Мацеёвицах, в бою под Кобылкой и в штурме Праги. Итак, мы можем с уверенностью сказать, что ни в штурме Очакова или Измаила, 
ни в итальянском и швейцарском походе Суворова Попадичев участия не принимал. Что касается службы его в Бутырском полку (Аустерлиц, 1812-й год, попадание в плен к французам), нам удалось разыскать в фондах РГВИА дело, в котором представлены месячные рапорты, именные списки солдат и офицеров и ведомости Бутырского пехотного полка за февраль 1812 - январь 1813 гг. (РГВИА. Ф. 489. Оп. 1. Т. 1. Ч. 1. Д. 136). Однако в силу технических причин это дело сейчас недоступно для исследователей.

«Выдумать» Илью Осиповича Попадичева для Назанского было абсолютно невозможно. А вот встретиться с ним в Пятигорске Назанский вполне мог. Не будем забывать, что он в эти годы проходил службу в Кавказском корпусе, а Пятигорск был любимым местом лечения и отдыха офицеров, которые приезжали с линии. Пятигорск был полукурортным городом (из-за желающих поправить здоровье на водах) и полувоенным (из-за обилия боевых офицеров). Попадичеву в это время около 8о лет. Он был достаточно прагматичен, чтобы понимать, какой интерес будет возбуждать у военных фигура седого старика с георгиевским крестом и медалями за Очаков и Измаил. Интерес к своей особе, уважение, угощение и выпивку можно было легко обеспечить, рассказывая то, что офицеры желали услышать - «о доблестях, о подвигах, о славе» старого времени. Назанский, естественно, мог сделать конспективные записи рассказов старика, однако он не обладал знанием стенографии и не мог заставить Попадичева «надиктовывать» свои рассказы.

Исходя из всех выявленных нами архивных материалов, можно сделать вывод, что текст воспоминаний Попадичева представляет собой сложную многослойную структуру, некий конгломерат сведений, проистекающих из различных источников. Безусловно, здесь присутствует слой его личных воспоминаний, и особенно значителен этот слой в описании деталей быта. Назанский вряд ли мог бы придумать такую деталь, о которой рассказывает Попадичев, описывая отработку ружейных приемов на зимних квартирах. Чтобы не заниматься этим под дождем и снегом, солдаты выкапывали ямы в крестьянских избах так, «чтобы четыре человека могли стать в них свободно и делать все приемы, не доставая потолка» (Воспоминания, 1895: 7).

Следующий слой - те факты, которые Попадичев мог слышать от своих собратьев по полку. Послужные списки Смоленского полка свидетельствуют, что в нем встречаются имена унтерофицеров, которые участвовали и в штурме Очакова, и в боях под Аккерманом или Бендерами. Хотя состав нижних чинов в полках XVIII столетия был величиной гораздо более постоянной, нежели состав офицеров, перемещения и среди них были возможны. После лазарета отставший от своего полка солдат вполне мог оказаться в составе другой части. А там, конечно, начинались рассказы, информация передавалась и усваивалась. Однако нужно учитывать, что в процессе такой устной коммуникации текст неизбежно начинал приобретать фольклорные черты.

Рассказывая о походе в Италию, Попадичев, например, описывает большой каменный мост, по которому они переправились через Дунай вскоре после Праги. «Мост, я вам доложу, сработан отлично; посредине устроен подъем для прохода судов, и так это все на нем ловко прилажено, что просто загляденье. Такого моста я и не видывал; на противной стороне был большой город, названья его не припомню» (Воспоминания, 1895: 73). Добавим от себя, Попадичев и не мог его видеть. Речь здесь идет о Каменном мосте в Регенсбурге1. Для того времени это был единственный мост через Дунай между Веной и Ульмом, и в период 1636-1791 гг. на нем действительно был разводной пролет, который из-за дороговизны содержания в 1791 г. был демонтирован, так что после этой даты видеть его было никак невозможно. Не мог такую деталь для убедительности вставить и Назанский. Совершенно ясно, рассказ о такой диковинке (в Петербурге первый разводной мост появился только в 1850 г.) бытовал в солдатской среде еще со времен Семилетней войны и передавался из уст в уста.

Кроме того, мы не можем исключать использование Попадичевым популярной литературы о Суворове для насыщения своего рассказа некими именами и географическими названиями. Такого рода сочинения к середине XIX в., как указывалось выше, уже были опубликованы, а Попадичев был достаточно грамотен, чтобы воспользоваться какими-нибудь «рассказами о Суворове для воспитанников военно-учебных заведений».

Автором же текста как такового выступает в нашем случае Иван Николаевич Назанский. Безусловно, он имел в своем распоряжении какие-то конспективные заметки, сделанные в Пятигорске. Однако, используя эти записи, он «сочинял» мемуары Попадичева, встраивая в них подходящие факты и события. Заимствуя у Милютина сведения о батальоне Санаева, он тем самым «легализовывал» рассказы Попадичева об участии в итальянском и швейцарском походе. Недаром в той части воспоминаний, где речь идет о событиях, в которых Попадичев действительно принимал участие, упоминаются имена командиров Смоленского полка (Г.И. Шевич, Ф.И. Тишинский [правильно - Кишенский], Н.А. Зубов, В.Н. Чичерин). При описании же сражений 1799 г. текст пестрит генералами и командирами корпусов (Милорадович, Багратион, Розенберг, РимскийКорсаков), а вот имен непосредственных своих командиров Попадичев почему-то не указывает.

1 Авторы приносят искреннюю благодарность сотрудникам музея истории судоходства на Дунае (г. Регенсбург), а также г-ну Лоренцу Байблю (Lorenz Baibl), возглавляющему городской архив Регенсбурга, за справочную информацию касательно Каменного моста. 
Трудным представляется вопрос об объеме редакторской правки, сделанной Масловским. Возможно, эта правка была минимальной. Как мы видели, сначала петербургский историк встретил рукопись с воодушевлением, однако по мере погружения в работу над примечаниями, он все более ясно видел несоответствия, для устранения которых требовалось не примечания составлять, а править сам текст. Эйфория сменилась разочарованием, и смертельно больной Масловский вряд ли был склонен тратить последние силы на «переписывание» сочинения генерала Назанского.

\section{5. Заключение}

Рассмотренные сюжеты проливают свет на обстоятельства появления «Воспоминаний суворовского солдата». Мы видим, что «мемуары Попадичева» не являются порождением собственно XVIII столетия, в не меньшей степени они выступают и фактом общего развития военно-исторической науки конца XIX в., со всеми присущими ей концептуальными противоречиями и столкновениями. Анализ особенностей этих мемуаров, их многослойной структуры, а также мотивов тех лиц, которые внесли свою лепту в процесс создания текста, - все это должно учитываться при работе с данным источником. И дело отнюдь не сводится к тому, чтобы доказать, что «Воспоминания суворовского солдата» составляют смесь из «баек старика-солдата» и литературного творчества генерала. На наш взгляд, они гораздо интереснее как факт сотворения «мифа о Суворове» - сначала в сознании солдат, а затем и в исторической памяти общества. Пусть Попадичев рассказывал свои небылицы молодым офицерам, перевирая события и даты, но в его рассказах, как в фокусе, отражалось главное - кристаллизация солдатских представлений об идеальном полководце, вслед за которым можно пойти хоть в пекло. Историческая же наука по природе своей (в нашем случае она нашла выражение в фигуре Масловского), проводя критический анализ и верификацию источников, выступает в роли природного оппонента мифа. Она разбирает его по кирпичикам, расчленяет по звеньям, стремясь провести деконструкцию мифа. Однако зачастую наука оставляет за скобками могучую иррациональную силу мифа и не пытается ответить на вопрос: а не сложись в солдатском сознании «миф о Суворове», был бы князь Италийский и граф Рымникский столь же успешен на полях сражений?

\section{Литература}

Барсов, 1889 - Барсов E.B. О научной деятельности Масловского в связи с избранием его адъюнкт-профессором военной Академии Генерального штаба // Московский листок. 1889. № 268 от 26 сентября.

Бескровный, 1962 - Бескровный Л.Г. Очерки военной историографии России. М., 1962. 318 с.

Библиотеки солдатские, 1911- Библиотеки солдатские // Военная энциклопедия. Т. 4. СПб., 1911. С. 537.

Богуславский, 1953 - Богуславский Г.А. Перечень русской литературы о А.В. Суворове, 17561952 гг.// А.В. Суворов. Документы. Т. 4 / Ред. Г.П. Мещеряков. М., 1953. С. 534-661.

Воспоминания Ивана Менышого, 1874 - Воспоминания Ивана Менышого. 1806-1822 // Русская старина. 1874. Том 10. С. 46-59.

Воспоминания, 1895 - Воспоминания суворовского солдата / Ред. Д.Ф. Масловский. СПб., 1895. $90 \mathrm{c}$.

Воспоминания. Очаков и Измаил, 1900 - Воспоминания суворовского солдата. Очаков и Измаил. СПб., 1900. 26 с.

Воспоминания. 1812-й год, 1901 - Воспоминания суворовского солдата. 1812-й год. Пребывание в плену у французов и освобождение. Спб., 1901. 22 с.

Воспоминания. Аустерлиц, 1903 - Воспоминания суворовского солдата. Аустерлиц. СПб., 1903. $25 \mathrm{c}$.

Воспоминания. Отставка, 1907 - Воспоминания суворовского солдата. Отставка. СПб., 1907. 35 с.

Годунов, Королев, 1908 - Годунов В., Королев А. История 3-го Уланского Смоленского императора Александра III полка: 1708-1908 г. Т. 1. Либава, 1908. 331 с.

Зайончковский, 1952 - Зайончковский П.А. Военные реформы 1860-1870 годов в России. М., 1952. $368 \mathrm{c.}$

Записки Памфила Назарова, 1878 - Записки солдата Памфила Назарова, в иночестве Митрофана. 1792-1839 гг. // Русская старина. 1878. Т. 22. № 8. С. 529-556.

Каталог, 1907 - Каталог книг, одобренных для ротных библиотек кадетских корпусов. СПб., 1907. $143 \mathrm{c.}$

Лопатин, 2012 - Лопатин В. С. Суворов. М., 2012. 447 с.

Масловский, 1894 - Масловский Д. Заметка по поводу статьи «Ларго-Кагульская операция» г. Петрова // Военный сборник. 1894. № 2. С. 168-174.

Масловский, $1892 \mathrm{a}-$ Масловский Д. Ларго-Кагульская операция графа П.А. Румянцева (17691770 гг.) // Военный сборник. 1892. № 8. С. 191-220.

Масловский, 1892b - Масловский Д. По поводу статьи «Нарвская операция 1700 г.» г. Петрова // Военный сборник. 1892. № 10. С. 219-231. 
Милютин, 1857 - Милютин Д.А. История войны России с Францией в царствование императора Павла І в 1799 г. Т. 3. Приложения. СПб., 1857. 652 c.

Немирович-Данченко, 1903 - Немирович-Данченко В.И. Скобелев. Личные воспоминания и впечатления. СПб., 1903. 358 с.

Новаковский, 1867 - Новаковский В. Рассказы о Суворове. Чтение для народа. СПб., 1867. 69 с.

ОР РГБ - Отдел рукописей Российской государственной библиотеки.

Охлябинин, 2004 - Охлябинин С.Д. Повседневная жизнь Русской армии во времена суворовских войн. М., 2004. 345 с.

Петров, 1892 - Петров А. По поводу Нарвской операции 1700 г. // Военный сборник. 1892. № 12. C. 231-255.

Петров, 1893 - Петров А. Ларго-Кагульская операция 1770 года (По поводу статьи г. Д. Масловского) // Военный сборник. 1893. № 12. С. 195-214.

Петров, $1893 \mathrm{~b}-$ Петров А.Н. Влияние русско-турецких войн с половины прошлого столетия на развитие русского военного искусства // Военный сборник. 1893. № 5. С. 5-34. $810 \mathrm{c}$.

Петрушевский, 1900 - Петрушевский А.Ф. Генералиссимус князь Суворов. 2-е изд. СПб., 1900.

Петрушевский, 1885 - Петрушевский А.Ф. Рассказы про Суворова. СПб., 1885. 238 с.

Полевой, 1852 - Полевой Н.А. Рассказы русского солдата. СПб., 1852. 125 с.

ПСЗРИ - Полное собрание законов Российской империи. Собрание 2-е. СПб., 1830-1885.

Потапов, 1845 - Потапов В.Ф. Александр Васильевич Суворов. Простонародный русский рассказ. М., $1845 \cdot 36 \mathrm{c}$.

Преснухин, 2021 - Преснухин $M$. Краткая биография Ильи Осиповича Попадичева. [Электронный pecypc]. URL: https://fligel-rota.ru/library/articles/kratkaya-biografiya-ili-osipovicha-popadicheva/ (дата обращения: 26.06.2021)

РГВИА - Российский государственный военно-исторический архив.

Слово Суворова, 2000 - Александр Васильевич Суворов: Слово Суворова. Слово современников. Материалы для биографии / Сост. С.Н. Семанов. М., 2000. 555 с.

Старков, 1847 - Старков Я.И. Рассказы Старого воина [псевд.] о Суворове. М., 1847. 482 c.

Mayzel, 1975 - Mayzel M. The Formation of the Russian General Staff. 1880-1917. A Social Study // Cahiers du Monde russe et soviétique. 1975. Vol. 16. No. 3/4 (Jul. - Dec., 1975), Pp. 297-321.

Wildman, 1980 - Wildman A.K. The End of the Russian Imperial Army. Princeton, Prinston Univ. Press, $1980.402 \mathrm{p}$.

\section{References}

Barsov, 1889 - Barsov, E.V. (1889). O nauchnoi deyatel'nosti Maslovskogo v svyazi s izbraniem ego ad"yunkt-professorom voennoi Akademii General'nogo shtaba [About Maslovsky's scientific activity in connection with his election as an associate professor at the Military Academy of the General Staff]. Moskovskii listok. № 268 ot 26 sentyabrya. [in Russian]

Beskrovnyj, 1962 - Beskrovnyj, L.G. (1962). Ocherki voennoj istoriografii Rossii [Essays on the military historiography of Russia]. Moscow, Akademiya nauk SSSR Publ., 318 p. [in Russian]

Biblioteki soldatskie, 1911 - Biblioteki soldatskie [Libraries of soldiers]. Voennaya entsiklopediya.

T. 4. SPb., 1911. P. 537.

Boguslavskij, 1953 - Boguslavskij, G.A. (1953). Perechen' russkoj literatury o A.V. Suvorove, 17561952 gg. [List of Russian literature about A.V. Suvorov, 1756-1952]. A.V. Suvorov. Dokumenty. T. 4. Red. G.P. Meshcheryakov. M. Pp. 534-661. [in Russian]

Godunov, Korolev, 1908 - Godunov, V., Korolev, A. (1908). Istoriya 3-go Ulanskogo Smolenskogo imperatora Aleksandra III polka: 1708-1908 g. [The history of the 3rd Ulan Smolensk Emperor Alexander III regiment: 1708-1908]. T.1. Libava: Libav. Vestn. Print, 331 p. [in Russian]

Katalog, 1907 - Katalog knig, odobrennykh dlya rotnykh bibliotek kadetskikh korpusov [Catalog of books approved for company libraries of cadet corps]. SPb., 1907. 143 p. [in Russian]

Lopatin, 2012 - Lopatin, V.S. (2012). Suvorov. M., 445 p. [in Russian]

Maslovskii, 1892a - Maslovskii, D. (1892). Largo-Kagul'skaya operatsiya grafa P.A. Rumyantseva (1769-1770 gg.) [Largo-Kagul operation of Count P. A. Rumyantsev (1769-1770)]. Voennyi sbornik. 8: 191-220. [in Russian]

Maslovskii, 1892b - Maslovskii, D. (1892). Po povodu stat'i «Narvskaya operatsiya 1700 g.» g. Petrova [About the article "Narva operation of 1700" by Mr. Petrov]. Voennyi sbornik. 10: 219-231. [in Russian]

Maslovskii, 1894 - Maslovskii, D. (1894). Zametka po povodu stat'i «Largo-Kagul'skaya operatsiya» g. Petrova [Note about the article "Largo-Kagul operation" by Mr. Petrov]. Voennyi sbornik. 2: 168-174. [in Russian]

Milyutin, 1857 - Milyutin, D.A. (1857). Istoriya vojny Rossii s Franciej v tsarstvovanie imperatora Pavla I v 1799 g. [The history of the war between Russia and France in the reign of Emperor Paul I in 1799]. 2-nd edit. vol.3. Prilozheniya. SPb., 652 p. [in Russian] 
Nemirovich-Danchenko, 1903 - Nemirovich-Danchenko, V.I. (1903). Skobelev. Lichnye vospominaniya i vpechatleniya [Skobelev. Personal memories and impressions]. SPb., 358 p. [in Russian]

Novakovskii, 1867 - Novakovskii, V. (1867). Rasskazy o Suvorove. Chtenie dlya naroda [Stories about Suvorov. Reading for the people]. SPb., 69 p. [in Russian]

Ohlyabinin, 2004 - Ohlyabinin, S.D. (2004). Povsednevnaya zhizn' Russkoj armii vo vremena suvorovskih vojn [Everyday life of the Russian Army during the Suvorov Wars]. M., 345 p. [in Russian]

OR RGB - Otdel rukopisei Rossiiskoi gosudarstvennoi biblioteki [Department of Manuscripts of the Russian State Library].

Petrushevskij, 1900 - Petrushevskij, A.F. (1900). Generalissimus knyaz' Suvorov [Generalissimo Duke Suvorov]. 2-nd edit. SPb., 810 p. [in Russian]

Polevoj, 1852 - Polevoj, N.A. (1852). Rasskazy russkogo soldata [Stories about Suvorov]. SPb., 125 p. [in Russian]

Potapov, 1845 - Potapov, V.F. (1845). Aleksandr Vasil'evich Suvorov. Prostonarodnyj russkij rasskaz

[Alexander Vasilyevich Suvorov. A simple Russian story]. M., 35 p. [in Russian]

PSZRI - Polnoe sobranie zakonov Rossiiskoi imperii [The complete collection of laws of the Russian

Empire]. Collection 2. SPb., 1830-1885. Archive].

RGVIA - Rossiiskii gosudarstvennyi voenno-istoricheskii arkhiv [Russian State Military-Historical

Slovo Suvorova, 2000 - Aleksandr Vasil'evich Suvorov: Slovo Suvorova. Slovo sovremennikov.

Materialy dlya biografii [Alexander Vasilyevich Suvorov: The Word of Suvorov. The word of contemporaries.

Materials for the biography]. Ed. S. N. Semanov. M., 2000. 555 p.

Starkov, 1847 - Starkov, Y.I. (1847). Rasskazy Starogo voina o Suvorove [Stories of an Old Warrior [pseudonym.] about Suvorov]. M., 482 p. [in Russian]

Vospominaniya, 1874 - Vospominaniya Ivana Men'shogo. 1806-1822 [Memories of Ivan the Lesser.

1806-1822]. Russkaya starina. 1874. Tom.10. Pp. 46-59. [in Russian]

Vospominaniya, 1895 - Vospominaniya suvorovskogo soldata [Memoirs of a Suvorov soldier]. Red.

D.F. Maslovskij. SPb, 1895.90 p. [in Russian]

Vospominaniya, 1900 - Vospominaniya suvorovskogo soldata. Ochakov i Izmail [Memoirs of a Suvorov soldier. Ochakov and Izmail]. SPb., 1900. 26 p. [in Russian]

Vospominaniya, 1901 - Vospominaniya suvorovskogo soldata. 1812-j god. Prebyvanie v plenu u francuzov i osvobozhdenie [Memoirs of a Suvorov soldier. The year is 1812. Being held captive by the French and being released]. SPb., 1901. 22 p. [in Russian]

Vospominaniya, 1903 - Vospominaniya suvorovskogo soldata. Austerlits [Memoirs of a Suvorov soldier. Austerlitz]. SPb., 1903. 26 p. [in Russian]

Vospominaniya, 1907 - Vospominaniya suvorovskogo soldata. Otstavka [Memoirs of a Suvorov soldier. Retirement]. SPb., 1907. 36 p. (in Russian)

Zajonchkovskij, 1952 - Zajonchkovskij P.A. (1952). Voennye reformy 1860-1870 godov v Rossii [Military reforms of 1860-1870 in Russia]. M., 368 p. [in Russian]

Zapiski, 1878 - Zapiski soldata Pamfila Nazarova, v inochestve Mitrofana. 1792-1839 gg. [Notes of the soldier Pamphil Nazarov, in the monastic life of Mitrofan. 1792-1839]. Russkaya starina. 1878. T. 22. 8: 529-556. [in Russian]

Mayzel, 1975 - Mayzel, M. (1975). The Formation of the Russian General Staff. 1880-1917. A Social Study. Cahiers du Monde Russe et Soviétique. 16(3/4): 297-321.

Wildman, 1980 - Wildman, A.K. (1980). The End of the Russian Imperial Army. Princeton, Princeton Univ. Press, 444 p.

\section{«Правда» и «ложь» суворовского солдата: Проблема авторства мемуаров Ильи Попадичева}

Татьяна Андреевна Володина a , ${ }^{*}$ Константин Андреевич Подрезов а

а Тульский государственный педагогический университет им. Л.Н. Толстого, Российская Федерация

Аннотация. В статье впервые в исторической науке анализируется специфика «Воспоминаний суворовского солдата» как исторического источника. Эти мемуары со времени своего появления (1895 г.) широко использовались в научной и популярной литературе. Впервые вводятся в научный оборот архивные документы, раскрывающие обстоятельства их появления, написания и публикации. Авторы анализируют мотивы и роль каждого из тех, кто внес лепту в формирование текста данного

\footnotetext{
* Корреспондирующий автор

Адреса электронной почты: volodina.tatiana2016@yandex.ru (T.А. Володина), kpodrezov@yandex.ru (К.А. Подрезов)
} 
источника: отставного солдата Ильи Попадичева, генерала И.Н. Назанского и военного историка Д.Ф. Масловского. В результате источник предстает как сложный комплексный текст, в котором выделяются слои, имеющие разное происхождение. Используя факты военной биографии реального Ильи Попадичева, авторы дают объяснение различной степени информативности и достоверности сведений, содержащихся в его воспоминаниях. Анализируя письма генерала Назанского к историку Масловскому, авторы раскрывают влияние различных факторов в работе генерала над мемуарами солдата: идейно-концептуального, прагматического и коммерческого. Раскрывается роль и значение Военно-ученого комитета Генерального штаба в формировании рынка массовой книжной продукции, предназначенной для обращения в войсках. В результате проведенного исследования авторы приходят к выводу, что воспоминания Попадичева являются не только отражением военноисторических реалий времен Суворова, но и в значительной степени выступают свидетельством сознательных усилий военного ведомства по индоктринации нижних чинов, а также фактом концептуальной борьбы в области военно-исторических исследований конца XIX в. Авторы доказывают, что именно с этим связана серьезная роль Д.Ф. Масловского в продвижении воспоминаний Попадичева. Однако в данном случае позитивистские принципы научности пришли в столкновение с базисом мифа. В статье раскрывается глубина моральной дилеммы, перед которой оказался военный историк Масловский. Наука требовала от него критического анализа текста в категориях источниковедения, а принципы «русской школы» - признания высоких научных достоинств этого же источника.

Ключевые слова: «Воспоминания суворовского солдата», Попадичев, Д.Ф. Масловский, военно-исторические исследования. 